\title{
Kidney Cancer Pathologic Regional Lymph Nodes TNM Finding v7
}

National Cancer Institute

\section{Source}

National Cancer Institute. Kidney Cancer Pathologic Regional Lymph Nodes TNM Finding v7. NCl Thesaurus. Code C89294.

A pathologic finding about one or more characteristics of kidney cancer, following the rules of the TNM AJCC V7 classification system as they pertain to staging of regional lymph nodes. (from AJCC 7th Ed.) 